\title{
Social and Economic Factors Influencing the Mortality of the Working-Age Population: Macroeconomic Approach
}

Olga Kozlova

\author{
Doctor of Economics, Professor, Chief of the Centre of the Socioeconomic Dynamics Research \\ Institute of Economics, the Urals Branch of Russian Academy of Science; Email: olga137@mail.ru
}

Mariya Makarova

Candidate of Economics, Junior Researcher at the Centre of the Socioeconomic Dynamics Research, Institute of Economics The Urals Branch of Russian Academy of Science; Email: maria_makarova87@mail.ru

\section{Elena Bedrina}

Candidate of Economics, Associate Professor at the Department of International Economy of Graduate School of Economics and Management, Ural Federal University Named After the first President of Russia B.N. Yeltsin, Senior Researcher at the Centre of the socioeconomic dynamics research, Institute of Economics, the Urals Branch of Russian Academy of Science Email: bedrina1967@mail.ru

\section{Yevgeniya Tukhtarova}

Senior economist at the Centre of the Socioeconomic Dynamics Research, Institute of Economics The Urals Branch of Russian Academy of Science; Email: tyevgeniya@yandex.ru

Doi:10.5901/mjss.2015.v6n6s5p102

\begin{abstract}
Nowadays Russia is under the economic reforms due to postindustrial development. The successful realization of this process requires elaborating how the population reacts on the reforms. The article is devoted to exploring the macroeconomic factors that influence on the mortality of the working-age population and are under the control of government. We obtained the indicators that characterize the dynamics of social and economic development. Then, they were divided into four groups such as macroeconomics, incomes, public health service, and disease rate. The statistical operations permitted to transform the indicators in every group in an integrated figure. Then the researchers conducted a regression analysis of the integrated figures and the mortality rates of the working-age population that proved the hypothesis of the research: the macroeconomic situation strongly influences the mortality rates of the working-age population. The obtained results should eliminate those fields of governmental policy being crucial for decreasing the mortality rates and, thus, for developing the human capital of Russia.
\end{abstract}

Keywords: mortality, working-age population, macroeconomics, public health, incomes.

\section{Introduction}

During the last years, Russian society has been under the different reforms such as reform of economic and social system, public health service, education etc. These reforms have resulted in the considerable consequences for the wellbeing of the working-age population. The accumulated statistics reflects that the effect of the reforms has been both positive (e.g. the rise of incomes) and negative (e.g. the degradation of health and mortality rates). These trends are supposed to influence greatly on the development of the national economy and national human capital.

There is a worldwide number of papers devoted to an impact of the governmental regulation on the well-being of the working-age population. They investigated how the macroeconomic indicators and non-economic factors influence on the mortality rates, longevity, and life expectancy.

Today, there are a very few studies in Russia that have investigated the correlation between well-being of the working-age population and macroeconomic dynamics. The researchers proved that the economic and non-economic factors result in the high mortality rates in Russia. Nevertheless, the effect of macroeconomic dynamics on the mortality rates of the working-age population has been underestimated. However, this knowledge is important to develop the 
realistic models of social and economic development of the country.

This paper examines the relationship between the macroeconomic dynamics and the mortality rates of the working-age population using the econometric calculations that eliminate how the mortality rates dynamics depends on such factors as the macroeconomic, public health service, incomes and disease indicators. The obtained models should identify the sensitive indicators of the mortality rates dynamics and detect the crucial fields of government regulation.

\section{Literature Review}

A wide set of researchers believe the macroeconomic dynamics to be the important factor of the mortality rates. For example, (Villegas and Haberman, 2014) proved that the differentials related to social and economic circumstances pose important challenges for the design of public policies for tackling social inequalities, as well as for the design of pension systems and the management of longevity risk in pension funds and annuity portfolios. Using England mortality data for socioeconomic subpopulations and the Lee-Carter model, they analyzed the impact of socioeconomic differences in mortality on the valuation of annuities.

Using data for six OECD countries over the period 1950-2006, Hanewald K. (Hanewald, 2011) studied the impact of macroeconomic fluctuations and cause of death trends on mortality dynamics in the Lee-Carter mortality forecasting model. The key results of this study were that the mortality rate correlated significantly with macroeconomic fluctuations; a few causes of death such as diseases of the circulatory system, influenza and pneumonia, and diabetes mellitus accounted for a large fraction of the variations in the mortality rate. Besides, the regression analysis (Hanewald, 2010) showed that sex- and age-specific mortality rates varied substantially in their response to external factors. Strongest associations were found with changes in real GDP, flu epidemics, and the two lifestyle variables - alcohol and cigarette consumption - in both univariate and multivariate setups. Further analysis indicated that these effects were primarily contemporary, whereas other indicators, such as weather conditions, exerted lagged effects.

Studying the mortality rates of the working-age population in Sweden, the researchers (Kondo et al., 2014) highlighted the rising gender gap of these indicators. They concluded that the income-based inequalities among workingage male and female Swedes had increased since the late 1990s, whereas in absolute terms the increase was less remarkable among men. Although structural and behavioral factors explaining this trend, such as the economic recession in the early 1990s, should be studied further.

Moreover, (Bengtssona and Poppel, 2011) argued that mortality was determined by non-economic factors, leaving little room for a social gradient in mortality. They also proved that the association between income and mortality observed nowadays most likely was a recent phenomenon. Overall, a causal link between income and mortality was put into question

Furthermore, some studies explored the impact of macroeconomic policy on the mortality rates. For example, (Howell and Okatenko, 2010) conducted the comparative analysis of the labor productivity growth in France and USA and it causes. They found that France had the well thought government policy included work-wage balance and placement of low qualified workers. At the same time, the USA labor policy was targeted on the self-employment of the working-age population. Such a stressful policy in the USA provoked the rise of the mortality rates and decrease of macroeconomic indicators. On the contrary, the French labor productivity was considerably higher than American one and the psychological state of the French working-age population more favorable.

According to (Pichelmann and Roeger, 2004), the structural transformations in economies of EU countries resulted in a reduction of incomes and degradation of human capital. Additionally, declining the quantity and quality of workingage population cased the economic decrease. Thus, the robust macroeconomic policy was supposed to be pursued for the sake of public development.

The research of the adequacy of human resources for the sustainable development of the territories of the Russian Arctic (Revich et al., 2014) showed the negative dynamics of the population and labor potential, gave actual forecasts of the declining life expectancy, and discussed the reasons for the high mortality rate, especially among working-age people. They concluded the need for priority measures to overcome the increasing mortality in the region and the development of the social and healthcare areas.

Unfortunately, only a few Russian studies investigating the linkage between the macroeconomics and the mortality rates of the working-age population were found. These included the studies of trauma mortality (Yumaguzin and Vinnik, 2014), life expectancy of the working-age population (Tikhonova and Gorchakova, 2010) and others. The researchers found that the behavioral, environmental and economic factors of risks have resulted in the high mortality rates in Russia. In addition, the structure of mortality parents has been degrading and converging the one of the countries with low living standard and poor public health service. Thus, it is an unexplored field for the research despite having a great importance 
for the social and economic development of Russia.

Aiming to estimate the life quality of the population in the Middle Urals of Russia, the previous research of the authors (Kozlova et al., 2015) showed that the life quality was deeply depended on the macroeconomic indicators, incomes of population, ecology, health rate, quality of public health and education services, and others. Moreover, it displayed that the demographic processes were also significant for the development of the life quality. Thus, the current research continues and enhances the exploration of the relationship between macroeconomic development and mortality dynamics.

\section{Methods}

This section describes the steps of analysis aimed to evaluate the impact of social and economic factors on the mortality rates of the working-age population. The database of Federal State Statistic Service of Russia provided the reliable indicators for the period of 2000-2013 years. We obtained the indicators that are under government regulation, and they are expected to be the targets of social and economic policy. The selected indicators were grouped in four target sets chosen for the purpose of the research; they are macroeconomics, public health service, income, and disease. Table 1 contains the full list of the involved indicators.

Table 1. List of indicators characterized the four target sets

\begin{tabular}{|l|l|l|l|}
\hline Macroeconomics & Public health service & Income & Disease \\
\hline GDP per capita, rubles & $\begin{array}{l}\text { Number of doctors per } 10 \\
\text { thousands of population }\end{array}$ & $\begin{array}{l}\text { Purchasing power of wages (per } \\
\text { subsistence minimum level) }\end{array}$ & $\begin{array}{l}\text { Disease rate per a thousand of } \\
\text { population: infectious and parasitic } \\
\text { diseases }\end{array}$ \\
\hline $\begin{array}{l}\text { Consumer price index, \% } \\
\text { of corresponding period } \\
\text { of previous year }\end{array}$ & $\begin{array}{l}\text { Number of nursing staff per } 10 \\
\text { thousands of population }\end{array}$ & $\begin{array}{l}\text { Population with money income } \\
\text { below subsistence minimum level, } \\
\% \text { of total population }\end{array}$ & $\begin{array}{l}\text { Disease rate per a thousand of } \\
\text { population: malignant tumours }\end{array}$ \\
\hline Unemployment rate, \% & $\begin{array}{l}\text { Power outpatient clinics per } 10 \\
\text { thousands of population }\end{array}$ & $\begin{array}{l}\text { Payment for housing and } \\
\text { communal services, \% of total } \\
\text { money expenditures }\end{array}$ & $\begin{array}{l}\text { Disease rate per a thousand of } \\
\text { population: diseases of the circulatory } \\
\text { system }\end{array}$ \\
\hline $\begin{array}{l}\text { Pace of GDP, \% of } \\
\text { corresponding period } \\
\text { of previous year }\end{array}$ & $\begin{array}{l}\text { Number of hospital beds per 10 } 10 \\
\text { thousands of population }\end{array}$ & $\begin{array}{l}\text { Number of cars per a thousand of } \\
\text { population }\end{array}$ & $\begin{array}{l}\text { Disease rate per a thousand of } \\
\text { population: diseases of the respiratory } \\
\text { system }\end{array}$ \\
\hline
\end{tabular}

The indicators of "Macroeconomics" set such as GDP per capita, consumer price index, unemployment rate are traditionally used to present the economic growth of a country. The indicators of "Public health service" set reflects the dynamics of the public health service development. The indicators of "Income" set characterize the well-being of the working-age population. And the indicators of "Disease" set display the main disorders being the parents of the mortality of the working-age population.

For the sake of using the statistical operations, all the indicators were converted in a comparable shape. The two cases are possible. If an analyzing indicator influences positively on the social and economic development, then formula (1) works.

$$
X^{\prime}=\frac{x-x_{\min }}{x_{\max }-x_{\min }}(1)
$$

If an analyzing indicator influences negatively the social-economic development, then formula (2) works.

$X^{\prime}=\frac{x_{\max }-x}{x_{\max }-x_{\min }}(2)$

$X^{\prime}$ - a converted index; $x$ - a certain meaning of an indicator; $x_{\min }, x_{\max }$ - the lowest and the highest meaning of an indicator accordingly. Thus, a converted index equal 1 means the best dynamics of an indicator, a converted index equal 0 means the worst dynamics of an indicator.

Then the four converted indexes of each set were united in an integrated figure that was equal the average meaning of them. The integrated figure takes a numeric interval [0; 1$]$. The value equal 1 means the best dynamics of an integrated figure, the value equal 0 means the worst dynamics of an integrated figure.

After all the mathematical operations, the correlation analysis was conducted based on four integrated figures (macroeconomics, public health service, income, and disease ones) and the mortality rate figure (the mortality rate of the working-age population converted by formula (2)). 


\section{Results and Discussion}

As mentioned previously, the aim of the analysis was to test the hypothesis about the correlation between macroeconomic trends and mortality rates of the working-age population. Figure 1 shows that the macroeconomics integrated figure rose during the 2000-2005 years; such a trend seemed to be the result of the devastating social and economic crisis in Russia since 1990s. Overcome of this crisis was reflected by the highest point of the macroeconomics integrated figure (accumulating the national welfare, declining inflation rate, creation the jobs) and the income integrated figure (reflecting the rising incomes) in 2007-2008 with providing the eventful social and economic policy thought to be resulted in the declining mortality rates of the working-age population.

It should be noticed that there are some intersection points of the macroeconomic and mortality graphs. The period of 2001-2008 years must have been the time needed to collect the positive effect of the macroeconomics transformations on the mortality rates of the working-age population. The next period of 2008-2010 reflects that the positive cumulative effect of previous reforms ought to have compensated a destructive influence of the world financial crisis on the macroeconomic indicators in Russia and maintained the positive mortality rate dynamics.

The period of accumulating the beneficial income effect on the mortality rates of the working-age population has been registered since 2006 (the intersection point of the relevant graphs), but has not finished yet. Thus, this period seems to be much longer and require avery thoughtful governmental policy.

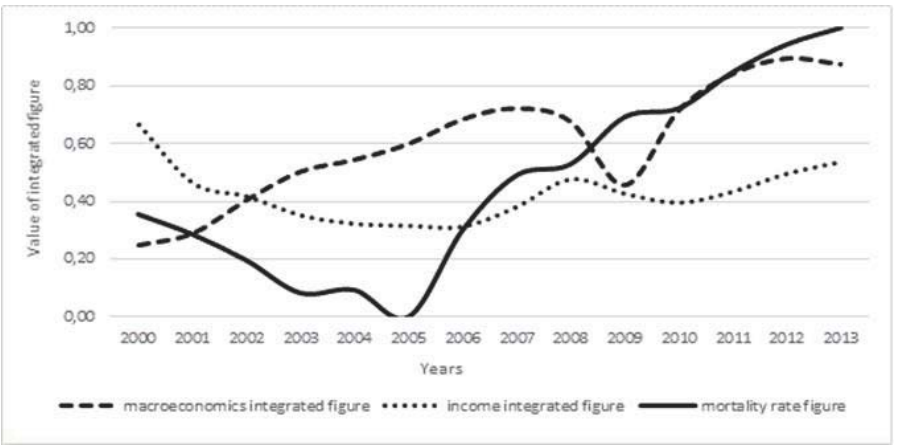

Figure 1. Dynamics of macroeconomics and income integrated figures and mortality rate figure

Source: Authors' calculations based on "Regions of Russia. Social and economic indicators: statistical yearbook. 20012014".

Furthermore, the improvement of macroeconomic situation influences on the mortality rates indirectly. The bigger budget revenues seemed to encourage the increasing financial support of the public health service. Since 2005 year, Russian government conducted a reform of the public health service that included implementation of an institute of family doctor, modernization of medical equipment and treatment methods. The reform has resulted in the development of the disease detection and cure. Thus, it improves the mortality rate of the working-age population (Fig. 2). The time lag was equal three years for the disease integrated figure (the intersection point in 2008) and five years for the public health service integrated figure (the intersection point in 2010).

Using the method of econometric modeling, we verified the results noticed above. Formula 3 shows the correlation between the macroeconomic situation and the mortality rate of the working-age population in Russia.

$M R=0.54$ * const $+0.21 * \mathrm{H}-1.50$ * $\mathrm{D}+0.30$ * $\mathrm{ME}+0.91$ *
s.e. $(0.44)$
(0.33)
(0.30)
$(0.20)$
$\mathrm{R}^{2}=0.95 \quad \mathrm{~F}_{\text {stat }}=41,3$

$M R$ - mortality rate figure, $H$ - public health service integrated figure, $D$ - disease integrated figure, $M E$ macroeconomics integrated figure, $I$ - income integrated figure.

As Formula 3 displays, the macroeconomics, public health service and income integrated figure influence on the mortality rate directly. The most sensitive factor among them is the income integrated figure with the elasticity coefficient being equal 0.91 . Besides, the disease integrated figure has an inverse correlation with the mortality one being the most sensitive and equal -1.5. 


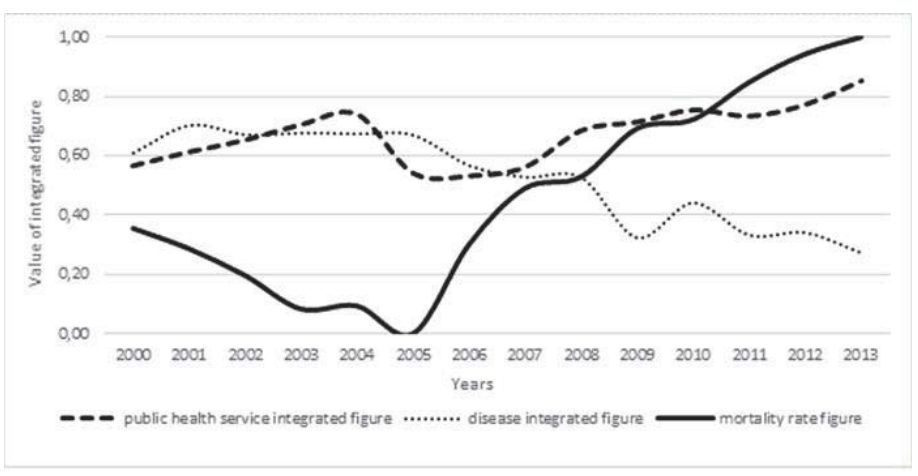

Figure 2. Dynamics of public health service and disease integrated figures and mortality rate figure

Source: Authors' calculations based on "Regions of Russia. Social and economic indicators: statistical yearbook. 20012014".

Thus, it should be emphasized that the indirect impact of macroeconomics (via public health service and disease rate) is stronger than direct one. Overall, it is evident from the presented results that the government ought to concentrate the most efforts on the decreasing the disease rates and increasing the incomes of working-age population in order to reduce the mortality rates and develop the national human capital.

\section{Conclusion}

Since the main objective of this work was to examine the relationship between the macroeconomic situation and the mortality rates of the working-age population, we used econometric modeling to identify the sensitive indicators of the mortality rates dynamics and to detect the crucial fields of government regulation. We have found that the mortality rates considerably depended on the development of the macroeconomics, public health service, incomes and disease rates. Our findings have confirmed the antecedent researches indicating the strong inverse influence of disease rate and strong direct influence of incomes on the mortality rates of the working-age population. Furthermore, we have detected that macroeconomics situation and functioning of the public health service had a considerable impact on the mortality rates.

This research highlights the significance of balanced social and economic governmental policy due to decrease the mortality rates and, thus, to develop national human capital. Although, it should be noted that the list of sensitive factors is not limited and other indicators need to be tested to create the most relevant model of the factorial influence on the mortality rates of the working-age population in Russia.

\section{Acknowledgements}

This article is supported by the Russian Foundation for Basic Research, project №15-06-09169 "Development of methodological tools for measuring and assessing the impact of socio-economic and demographic factors on the mortality of the working-age population".

\section{References}

Bengtssona, T., \& Poppel, F. (2011). Socioeconomic inequalities in death from past to present: an introduction. Explorations in Economic History, 48(3), 343-356.

Hanewald, K. (2011). Explaining mortality dynamics: The role of macroeconomic fluctuations and cause of death trends. North American Actuarial Journal, 15(2), 290-314.

Hanewald, K. (2010). Factors driving aggregate mortality rates in postwar Germany. Zeitschrift für die gesamte Versicherungswissenschaft, 99(2), 211-229.

Howell, D.R., \& Okatenko, A. (2010). By what measure? A comparison of French and US labor market performance with new indicators of employment adequacy. Journal of Applied Economics, 24(3), 333-357.

Kondo, N., Rostila, M., \& Yngwe, M. A. (2014). Rising inequality in mortality among working-age men and women in Sweden: a national registry-based repeated cohort study, 1990-2007. Journal of Epidemiology and Community Health, 68(12), 1145-1150. 
Kozlova, O., Gladkova, T., Makarova, M., \& Tukhtarova, E. (2015). Kachestvo zhizni naseleniya: voprosi otsenki [Life quality of population: the problems of estimation]. Ekonomist, 8, 80-87.

Pichelmann, K., \& Roeger, W. (2004). The EU growth strategy and the impact of aging. Journal of International Economics, 12(2), 213232.

Revich, B., Kharkova, T., Kvasha, E., Bogoyavlenskii, D., Korovkin, A., \& Korolev, I. (2014). Sociodemographic limitations of the sustainable development of Murmansk oblast. Studies on Russian Economic Development, 25(2), 201-206.

Tikhonova, G., \& Gorchakova, T. (2010). Smertnoct' i prodolzhitel'noct' zhizni naseleniya trudosposobnogo vozrasta v Rossii: metodi i rezul'tati issledovaniya [Mortality and longevity of working-age population of Russia: methods and results of the research]. Medicina truda i promishlennaya ecologiya, 3, 1-6.

Villegas, A. M., \& Haberman, S. (2014). On the Modeling and Forecasting of Socioeconomic Mortality Differentials: An Application to Deprivation and Mortality in England. North American Actuarial Journal, 18(1), 168-193.

Yumaguzin, V., \& Vinnik, M. (2014). Factori smertnosti ot vneshnikh prichin i puti ejo snizheniya: opit ekspertnogo interviyu [External factors of mortality and ways of its decreasing: experience of experts' interview]. Electronniy zhurnal «Social'niye aspekti zdoroviya naseleniya» [Online] Available: http://vestnik.mednet.ru/content/view/595/30/ (September 28, 2015). 